\title{
The Implementation of Communicative Language Teaching in English Practice
}

\author{
Arini Sabrina \\ Plantation Crop Farming \\ Politeknik LPP Yogyakarta \\ Indonesia \\ arinisabrina91@gmail.com
}

Citation: Sabrina, Arini. (2020). The Implementation of Communicative Language Teaching in English

Practice. Notion: Journal of Linguistics, Literature, and Culture, Vol 2(1), p. 17-27.

DOI: http://doi.org/10.12928/notion.v2i1.1750

\begin{tabular}{|c|c|}
\hline Article Info & ABSTRACT \\
\hline $\begin{array}{l}\text { Article History } \\
\text { - Article Received } \\
13^{\text {th }} \text { February } 2020 \\
\text { - Article Accepted } \\
15^{\text {th }} \text { April } 2020\end{array}$ & $\begin{array}{l}2013 \text { Curriculum now has been implemented so widely in Indonesia, especially in } \\
\text { English teaching and learning process. It delineates some focal points like student- } \\
\text { centered active learning and contextual teaching which hopefully brings the students } \\
\text { to learn more effectively. Furthermore, there is an apparent unanimity that the } \\
\text { curriculum may lead the meaningfulness of learning. In relation to English teaching } \\
\text { approach, Communicative Language Teaching (CLT) is likened to the latest } \\
\text { curriculum. CLT emphasizes on the context and authenticity. Thus, this approach } \\
\text { should go along with } 2013 \text { Curriculum. This study aims at finding out the } \\
\text { implementation of CLT in line with the curriculum, since many previous studies } \\
\text { alert some problems happening while CLT is applied not in ESL as its birthplace, } \\
\text { yet in EFL context. In fact, Indonesia perceives English as foreign language. But, } \\
\text { there are still few studies related to this approach. After observation and document } \\
\text { tracking are conducted, it is concluded that Scientific Approach and Communicative } \\
\text { Language Teaching Approach are able to blend to create more effective } \\
\text { communicative learning. }\end{array}$ \\
\hline
\end{tabular}




\section{Sabrina, Arini \\ The Implementation of Communicative English language Teaching in English Practice}

\section{INTRODUCTION}

Teaching practice is reliant on the theory used. When a teacher has broad insight on the teaching theories, it can be assumed that the teaching and learning process will always be fun and varying. This can be understood as the teacher can adjust the teaching methods with the students' interest, their conditions or moods, the availability of media, etc.

English teaching is one of the teaching practices having bunches of interesting theories. They cover what both the students and the teacher need. Born from the theories, some approaches and methods give various choices for English teachers. The approaches as well as methods offered are such as Silent Way, Desuggestopedia, Content-Based Instruction, and Communicative Language Teaching.

To be specific, Communicative Language Teaching is happening nowadays, without neglecting some other ways that can also be applied in the classroom. This approach has some characteristics that foster the students to be active to use language as a means of communication, not merely as the material studied. Thus, the students, taught using this approach, are expected to use language as it should be.

As the approach is suggested to use, the latest curriculum in Indonesia appeared: 2013 Curriculum. This curriculum brings the similar characteristics to the Communicative Language Teaching Approach. From this rationale, this study presents the discussion on the blending of the approach with the curriculum implementation in SMP N 2 Pemalang, as the setting of the observation and document tracking.

\section{Communicative Language Teaching}

Communicative Language Teaching (CLT) or Communicative Approach is a transformation of viewing a language. In the past, language was viewed as something discrete and apart from context. Learning a language was then regarded as learning many formulas in an obtrusive way. Consequently, many students got confused when they had to jump from the learning a language in their classes into the real language practice. But, as time went by, CLT offered refreshment for the way the language experts and practitioners viewed language learning.

As the name, Communicative Approach regards language learning as a whole learning using various contexts to make the students be able to communicate well. Richards and Rodgers[1] support it by saying that the goal of language teaching is to develop communicative competence which was what speaker needs to know in order to be communicatively competent in a speech community. To give more detailed information, Canale and Swain in Sreehari[2] also break the competence into four dimensions: grammatical competence (sentence-level grammatical forms), discourse competence (cohesion and coherence), sociolinguistic competence (social context understanding), and strategic competence (strategies to cope with various contexts).

In differentiating this approach to the other ones, there are some characteristics of Communicative Language Teaching. Larsen-Freeman[3] elaborates that the most obvious characteristic of CLT is that almost everything is done with a communicative intent. Then, authentic materials are also used to support the teaching and learning practices. The last one is that the activities are often carried out by the students in small groups, although Savignon[16] emphasizes that conducting small group activities should not be considered as an essential feature, and sometimes it is inappropriate in some contexts. Then, Asassfeh, et. al[4] contend that CLT is more about meaning than form. However, Thompson[5] adds that grammar teaching is also possible in conveying CLT after the students are expose to the context and function.

Richards and Rodgers[1] add some points regarding the characteristics, especially in viewing a language:

1. Language is a system for the expression of meaning.

2. The primary function of language is to allow interaction and communication.

3. The structure of language reflects its functional and communicative uses. 
4. The primary units of language are not merely its grammatical and structural features, but categories of functional and communicative meaning.

In line with them, Nunan in Banciu and Jireghie[6] also lists the features of CLT as follows:

1. an emphasis on learning to communicate through interaction in the target language,

2. the introduction of authentic texts into the learning situation,

3. the provision of opportunities for learners to focus, not only on language but also on the learning management process,

4. an enhancement of the learner's own personal experiences as important contributing elements to classroom learning,

5. an attempt to link classroom language learning with language activities outside the classroom.

Related to the implementation of this approach in English education, many studies encounter some problems. The first and foremost, the application is burdened by the cultural diversity in learning. Say, for example, Chen[7] points out that discussions and pair works as special characteristic activities in CLT cannot be smoothly held, since these are rarely used in Japanese teaching culture. Nishino[8] adds that Japan is accustomed with large classes in learning process. In fact, CLT usually triggers small classes to promote optimum discussions. The second one is about the lack of training and resources for both the teachers and the students. The studies from Jacobs and Farrell[9], also Chang and Goswami[10] emphasize that some teachers who were not perfectly prepared for the CLT approach in teaching process, as a consequence, have little knowledge and teaching skills about CLT. Next, lack of English environment becomes the other obstacle. Hiep[11] supports it by saying that in Vietnam, many students share the same mother tongue which is obviously not English. Many of them prefer using their mother tongue than English in daily conversation. This also leads to students' lack of English competence which can be another barrier in fostering CLT approach in the class. Ozsevik[12] reports that the students' low English proficiency makes it difficult for the teachers to come up with lively English class.

Chang[13] then recommends further study to find out the more detailed CLT practice and teachers' attitudes towards CLT. Some experts revealing the problems aforementioned also conduct their studies not in Indonesia. Hence, this study emerges to find out the implementation of CLT, whether or not it also has the same problems.

\section{Curriculum Overview}

When the time runs, when everything changes, the educational system, called as curriculum, usually transforms its form or content, too. The curriculum will be adjusted to the demands. It also happens in Indonesia, which has changed its curriculum for several times. The aim is right; improving the quality of education. Thus, 2013 Curriculum was established.

Compared to the prior curriculum, 2013 Curriculum brings something new without leaving some inheritance from School Level Curriculum. The new curriculum is the improvement of the prior one based on the Act number 19 in 2005[14] about national standards of education. This regulation is then revised in the form of the Act number 32 in 2013[15]. One of the changes is in the teaching and learning process. There are some characteristics of this curriculum such as optimizing student-centered active learning and contextual teaching, using scientific approach through five steps (observing, questioning, collecting information, associating, and communicating), and encouraging the students to find the answers by themselves (discovery learning).

\section{METHODOLOGY}

This research is qualitative in nature. Observation and document tracking were conducted to scrutinize the teaching practice as well as the theories used. In the discussions, the writer compared the plan and the implementation of teaching process. Besides, the writer analyzed further about the teaching approach or method used, blended with the application of Scientific Approach as the teaching guidelines of 2013 Curriculum in Indonesia. Through the field note based on the observation, the writer gained much information on the ways she taught the students. Furthermore, the documents tracked were fruitful in fitting the plan and the real implementation of English teaching there.

Furthermore, the writer merely observed one class. Grade 8 class in SMP N 2 Pemalang was selected to be observed on 20 November 2014. Specifically, the 
students from 8 B voluntarily participated in the observation. These students have been learning using the latest curriculum since they were on the seventh grade. In relation to the school itself, SMP $\mathrm{N} 2$ Pemalang is one of the most well-known secondary schools in Pemalang. This school was once selected to be the candidate of international standardized school Now, this school is growing along with the implementation of 2013 Curriculum that is revised all over the time.

\section{RESULT AND DISCUSSION}

\section{Communicative Language Teaching and Scientific Approach Blending Realization}

The Communicative Language Teaching seems to proliferate every day, especially in the implementation of 2013 Curriculum in Indonesia. From the observation, a field note was yielded to analyze further after this. The complete field note is presented below:

Field Note of English Teaching 8 B, SMP N 2 PEMALANG. Thursday, 20 November 2014, period $1-2$

The teacher used English from the first time she entered the classroom. She greeted the students and then asked them if there was a student who was absent that day. The teacher then stimulated the students to use English to answer her question by using English when questioning them. The students finally answered using English about who was absent and the reason. After that, the class was started through prayer led by the class leader. After praying, the students and the teacher opened their textbooks on chapter 5, talking about the theme "My Uncle is a zoo keeper". The teacher also presented the material on the slide screen. She then introduced the topic to the students, and moved to a picture of zoo with some animals and things around $i$. The teacher ordered the students to observe the picture carefully. The teacher asked the students about what the picture was about. She then stimulated the students to mention what were in the picture. The students then answered using English.

The teacher then asked the students how to ask about quantity of people in the roo. The students were then belped to structure a question "How many people are in the zoo?". From that, the teacher then led the students to make similar questions with the use of picture or the real situation in the classroom. The teacher then asked some students in pairs to read a question with the answer in the textbook using a term few. From this, the students were asked about the meaning of few in Indonesian. The teacher then explained it. After that, the students were asked to read the expressions using term much. Again, the teacher asked the students about its meaning and the different use of much compared to many. The teacher explained the students about the countable and uncountable nouns. From the explanation, the teacher asked the students to mention the examples.

After that, the teacher asked the students to read some expressions related to the zoo, focusing on the verbs frequently used. She offered the students chance to question her if there was difficult word. The students then asked her about some difficult verbs like takes care, prepares, etc. Next, the teacher asked the students to do individual task of completing some sentences with the first sentence had been completed as an example. While the students did the task, the teacher went around the class to check them. After some minutes, the students were asked to read the answer one by one. In checking the students' work and giving explanations, sometimes the teacher switched the language into the native one. After that, she asked the students if there was a question. Seeing there was no question, the teacher continued with asking the students to read aloud some expressions on the slide. After reading the expression, she asked the students whether they met some difficult words. Some students found some difficult words like a lot of, often, etc. which were translated by the teacher together with the students.

After that, the teacher continued with asking the students to read other expressions on the slide. She then asked them again to complete the expressions following individually. When the students finished their work, the teacher pointed some students to come forward to write down their work on the whiteboard. Soon after that, the teacher checked their work and asked the students if there was any problem.

The class was continued with an outdoor activity instructed in the textbook. The students were asked to go outside the yard and write down anything they met in their books. The activity took about 10 minutes. Finally, the students were asked to go back to the class when the bell was ringing. The class was over when the teacher said farewell to them all.

Figure 1. Field note of English Teaching 
To make the field note more systematic, the writer provides the points of teaching process in a listing form below:

1. The teacher greeted the students and led them to pray.

2. The teacher introduced the topic to the students.

3. The teacher asked the students to observe a picture in the textbook.

4. The teacher asked the students some question related to the picture.

5. The teacher explained the students about materials of describing the quantity, focusing on few, much, many, and so on.

6. The teacher asked the students to complete some sentences.

7. The teacher asked them to read the answers.

8. The teacher gave some expressions to practice by the students.

9. The teacher asked the students to complete some sentences.

10. The teacher asked some students to come forward and write down their answers.

11. The teacher instructed the students to go to the school yard to observe and write down things they met.

12. The teacher called the students back to the class when the bell was ringing.

13. The teacher ended the class.

As stated previously, Communicative Language Teaching highlights the teaching process in Indonesia, especially focusing in English. This approach fosters the students to be active in using English as a means of communication. Thus, the teaching process is always related to student-centered activities and the context. It was also reflected in English teaching process in SMP N 2 Pemalang.

To start with, the teacher did apperception. In this step, the teacher greeted the students and asked if there was absent on that day, followed with praying together. The following part of field note might explain:

The teacher used English from the first time she entered the classroom. She greeted the students and then asked them if there was a student who was absent that day. The teacher then stimulated the students to use English to answer her question by using English when questioning them. The students finally answered using English about who was absent and the reason. After that, the class was started through prayer led by the class leader.

\section{Figure 2. Field Note of English Teaching}

These opening activities can be regarded as the starting point to collect the students' attention and focus on English. Through observation, the teacher was also seen to speak in English to wake the students' awareness up. Besides, it encouraged the students to use English as much as they could. In relation to the discussed approach, the teacher who provides spaces for the students to speak in English contextually characterizes the Communicative Language Teaching. In this case, there was two-way interaction in which both the teacher and the students have chances to communicate. It is different from one-way interaction in which the students only listen to the lecture, for example.

The next activities might belong to the scientific approach which the latest curriculum uses. The scientific approach covers five stages. The first stage is observing. Through this step the teacher leads the students about the topic. Thus, sometimes this activity is labeled as lead-in. Pictures, dialogues, stories, videos, or songs can be the appropriate choices for the teacher to introduce the topic. Through looking at a picture of situation in a market, for instance, the students can predict what is going to learn next. In the case of $8 \mathrm{~B}$ Class, the topic of that day was about Zoo keeper. The excerpt of field note below can justify the observing stage:

After praying, the students and the teacher opened their textbooks on chapter 5, talking about the theme "My Uncle is a zoo keeper". The teacher also presented the material on the slide screen. She then introduced the topic to the students, and moved to a picture of zoo with some animals and things around $i t$. The teacher ordered the students to observe the picture carefully.

Figure 3. Field Note of English Teaching

From the excerpt above, the teacher was successful in introducing the topic, equipped with the good textbook containing interesting pictures and arranged learning steps. In the process, the students were seen to focus on the picture provided. The way of presenting a picture fits the students' interest and prevents the boring teaching process in which the 


\section{Sabrina, Arini \\ The Implementation of Communicative English language Teaching in English Practice}

teacher only explains the written materials. Also, the picture given represents the theory of language proposed by Communicative Language Teaching, saying that the context is prominent. Moreover, it is useful to give the students a chance to dive in their silent period or pre-production. In this period, the students can extract the knowledge and transfer it to their minds. The picture below is the lead-in picture of the topic discussed:

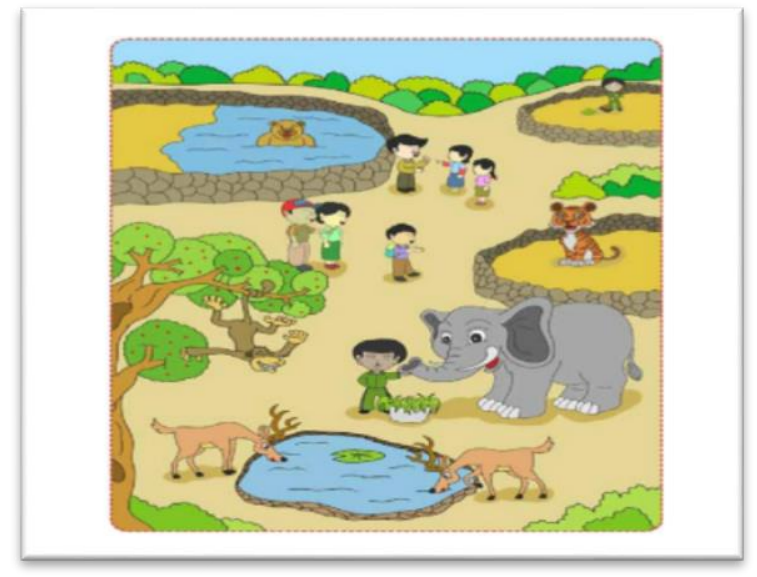

Picture 1. The Lead-in Picture of the Topic Discussed

Besides being successful in introducing the topic, the teacher was also well-prepared with the media. The teacher intentionally prepared all the materials from the textbook in power points. Besides, although there was projector in the classroom, the teacher chose to do the teaching and learning process in the multimedia room. In this room, there was a big screen to show the slides with some good supporting media. The teacher's decision is good at least for two reasons. The first one is that the students can feel another atmosphere in learning something. The last, the more complete media in the multimedia room can enhance the material presentation.

The next stage is questioning. The teacher, in this stage, might question the students about the topic or pictures presented before. The students can also do vice versa. They can ask the teacher some questions about the topic. The teacher writes down this step in her lesson plan below:

a) Dengan bimbingan guru peserta didik merumuskan pertanyaan terkait dengan isi, fungsi sosial, dan struktur teks, serta unsur kebahasaan dalam video yang telah disaksikan. (With assistance from the teacher, the students propose a question related to the content, social function, generic structure, and language features in the video viewed.)

b) Dengan bimbingan guru merumuskan pertanyaan tentang bagaimana menyatakan dan bertanya orang, binatang, atau benda dalam jumlab tertentu. (With assistance, the teacher proposes a question on how to state and ask about people, animals, or things in certain quantity.)

c) Dengan bimbingan guru peserta didik merumuskan pertanyaan tentang bagaimana menyatakan dan bertanya orang, binatang, atau benda dalam jumlah tertentu. (With assistance from the teacher, the students propose a question on how to state and ask about people, animals, or things in certain quantity).

Figure 4. Lesson Plan

From the observation, the teacher was seen to get the role in asking. She proposed some questions related to the topic to the students, stimulating them to communicate using English and focusing on the materials given. The teacher activity of asking the students can be seen from the following excerpt of field note:

The teacher asked the students about what the picture was about. She then stimulated the students to mention what were in the picture. The students then answered using English.

Figure 5. Field Note of English Teaching

There are four aims of questioning step. Firstly, questioning is helpful in activating the students' attention to the materials. Second, it is suitable for digging the students' background knowledge of some things that they have already known. The third one is to equalize the understanding of the topic and to adjust it to the new knowledge. Therefore, the students can collect much information to structure better understanding on the following materials. The fourth aim is to publish the implementation of Communicative Language Teaching. When the students are active in either asking or answering, this directly implies a good application of Communicative Approach.

Collecting information becomes the third stage. In this stage, the students will acquire much information from both the materials and the teacher in relation to extracting new knowledge. Likewise, the teacher will 
get great chance to give input flooding to the students so that they can synthesize and apply the core of the materials. Based on the observation, the teacher provides some examples and questions to the students. The justification is presented below:

The teacher then asked the students how to ask about quantity of people in the zoo. The students were then helped to structure a question "How many people are in the zoo?". From that, the teacher then led the students to make similar questions with the use of picture or the real situation in the classroom.

Figure 6. Field Note of English Teaching

From this, it is known that the teacher did some procedures. She initially stimulated the students by proposing a question. From the question, the teacher introduced the material on asking about the quantity. The students were then helped to acquire the information on structuring the questions. In other words, teacher gives the students explanations on the materials presented. However, the students are expected not only to gain the information from the teacher, but also from other sources such as books, internet websites, even their own friends.

Besides collecting information on asking about the quantity as the major material, the teacher also exposed the students to the minor information such as the use of few, much, etc. The following excerpt gives the explanation:

The teacher then asked some students in pairs to read a question with the answer in the textbook using a term few. From this, the students were asked about the meaning of few in Indonesian. The teacher then explained it. After that, the students were asked to read the expressions using term much. Again, the teacher asked the students about its meaning and the different use of much compared to many. The teacher explained the students about the countable and uncountable nouns.

Figure 7. Field Note of English Teaching

The teacher procedures explained before show that these apply the characteristics of Communicative Approach. The teacher not only delivered the explanations, but also interacted with the students and stimulated them to involve in the active learning process. From the excerpt, it can be seen that the teacher questioned the students and asked them to practice.

Besides collecting information, there is associating as the fourth step. During this process, the teacher will decrease help and let the students do some assignments. The students are expected to be more independent and bold in associating the materials acquired with the existing understanding. From the observation, the teacher was seen to motivate the students to associate the explanation given with some examples they can tell to the teacher. The further description is as follows:

The teacher explained the students about the countable and uncountable nouns. From the explanation, the teacher asked the students to mention the examples.

Figure 8. Field Note of English Teaching

Moreover, associating can be maximized through completing some tasks. In this case, the students of 8 B were asked to complete some sentences with some words discussed before. But, initially, the first number has given the sentence example. This is what is socalled as associating, where the students associate the example with their understanding. The following is the description of the situation:

Next, the teacher asked the students to do individual task of completing some sentences with the first sentence had been completed as an example. While the students did the task, the teacher went around the class to check them.

Figure 9. Field Note of English Teaching

There are some points about the field note above. The comparing activities are intended to stimulate the students to associate the materials. Furthermore, these activities are covered in some tasks given by the teacher. Unfortunately, in practice, the students were seen not to work together with the others. It is because each desk is only for one student. The teacher also did not instruct them to collaborate. This is what the teacher missed, since collaboration is needed in helping the students structure their understanding. Moreover, this collaboration is also one of the characteristics of Communicative Language Teaching.

After associating, the students will face the communicating process. Through communicating, the students will produce something that has been constructed before, that is the whole knowledge of the materials acquired. The activities might be making a journal, delivering a speech, etc. This stage also needs assistance from the teacher. The role of the teacher is to make the students brave in giving opinions, answering, writing, debating, and so on. But, like scaffolding, the teacher needs to decrease the aids or help for the students. This aims at making the students 
really understand the materials and walk the way independently. As they can do the task by themselves, self-pride may emerge and finally motivates them to do more and better.

Again, in relation to the responsibility of the students, they need to be able to communicate with the language learned. In this case, the language is English. Therefore, the teacher will encourage the students to speak or write using English. From the observation, there was a good example where the students did the written tasks and came forward to write down their answers on the whiteboard. For the further description, the field note below is provided:

After that, the teacher continued with asking the students to read other expressions on the slide. She then asked them again to complete the expressions following individually. When the students finished their work, the teacher pointed some students to come forward to write down their work on the whiteboard.

Figure 10. Field Note of English Teaching

The activities previously mentioned sum up all the materials discussed. The students are expected to understand the materials as a whole part and communicate it to both the teacher and the other students. The depiction of the situation is also provided below:

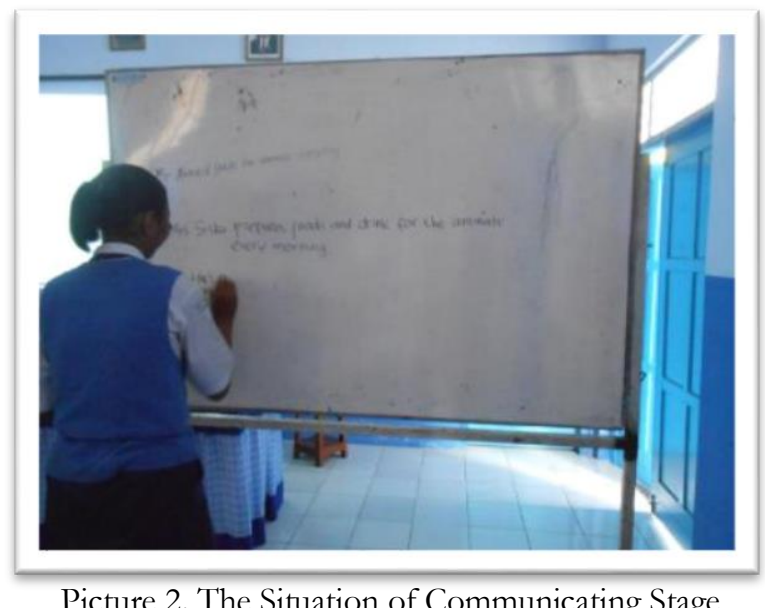

Picture 2. The Situation of Communicating Stage

In accordance with the approach focused, the communicating stage brings the important point of Communicative Language Teaching, where the students can practice using the foreign language. To facilitate it, the communicating stage provides some tasks for the students to complete, even to perform their ability using foreign language through the tasks as well, either spoken or written. In the case of English teaching in the class of $8 \mathrm{~B}$, the teacher let the students to show their ability of English by writing some sentences on the whiteboard.

Besides completing the sentences, the students were also asked to do observation outside the class. They were asked to write down whatever things they met. This was intended to complete another task in communicating step. The field note part below can justify:

The class was continued with an outdoor activity instructed in the textbook. The students were asked to go outside the yard and write down anything they met in their books.

Figure 11. Field Note of English Teaching

Unfortunately, the process could not be completed. The observation done by the students finally had to be stopped as the time was up. The activity was then ended by the teacher. This last part can be viewed below:

The activity took about 10 minutes. Finally, the students were asked to go back to the class when the bell was ringing. The class was over when the teacher said farewell to them all.

Figure 12. Field Note of English Teaching

\section{Language Goals}

The next point to be discussed is about the language goals that are expected. But, before the specific language goals are presented, some core competencies (Kompetensi Inti) as the big generic umbrella of teaching and learning process and basic competencies (Kompetensi Dasar) as the derivative points of the preceded core competencies are shown below. These are the points to consider before teachers make a lesson plan:

\section{a. Kompetensi Inti (core competencies)}

KI 3: Memahami dan menerapkan pengetabuan (faktual, konseptual, dan prosedural) berdasarkan rasa ingin tabunya tentang ilmu pengetahuan, teknologi, seni, budaya terkait fenomena dan kejadian tampak mata.

Understanding and applying knowledge (factual, conceptual, and procedural) based on the curiosity 
about science, technology, art, and culture related to visible phenomena and events

KI 4: Mengolah, menyaji, dan menalar dalam ranah konkret (menggunakan, mengurai, merangkai, memodifikasi, dan membuat) dan ranah abstrak (menulis, membaca, menghitung, menggambar, dan mengarang) sesuai dengan yang dipelajari di sekolah dan sumber lain yang sama dalam sudut pandang/teori.

Processing, presenting, and thinking in concrete ways (using, disentangling, stringing, modifying, and creating) and abstract ones (writing, reading, calculating, drawing, and composing) based on the materials learned at school and other sources within similar point of view

b. Kompetensi Dasar (basic competencies)

1) Mensyukuri kesempatan dapat mempelajari bahasa Inggris sebagai bahasa pengantar komunikasi Internasional yang diwnjudkan dalam semangat belajar

Being grateful for every chance to learn English as international language which is built in the form of learning spirit

2) Menunjukkan perilaku santun dan peduli dalam melaksanakan komunikasi interpersonal dengan guru dan teman.

Showing politeness and care in the interpersonal communication with the teacher and friends

3) Menunjukkean perilaku jujur, disiplin, percaya diri, dan bertanggung jawab dalam melaksanakan komunikasi transaksional dengan guru dan teman.

Showing honesty, discipline, confidence, and responsibility in the transactional communication with the teacher and friends

4) Menunjukkean perilaku tanggung jawab, peduli, kerjasama, dan cinta damai, dalam melaksanakan komunikasi fungsional.

Showing responsibility, care, cooperation, and peacefulness in the functional communication

5) Menerapkan struktur teks dan unsur kebahasaan untuke melaksanakan fungsi sosial menyatakan dan menanyakan keberadaan orang, benda, binatang dalam jumlah yang tidak tertentu, sesuai dengan konteks penggunaannya
Applying text generic structure and language features in doing social function of stating and asking about the existence of people, things, and animals in uncertain quantity, based on the contest of use.

6) Menyusun teks lisan dan tulis untuk menyatakan dan menanyakan tentang keberadaan orang, benda, binatang dalam jumlah yang tidak tertentu, dengan memperbatikan fungsi sosial, struktur teks, dan unsur kebahasaan yang benar dan sesuai konteks

Composing spoken and written texts to state and ask about the existence of people, things, and animals in uncertain quantity by considering social context, generic structure, and language features which are correct and contextual.

\section{Figure 13. Lesson Plan}

The previous points are also described in the textbook used by both the teacher and the students. The figure below tells about the chapter objective:

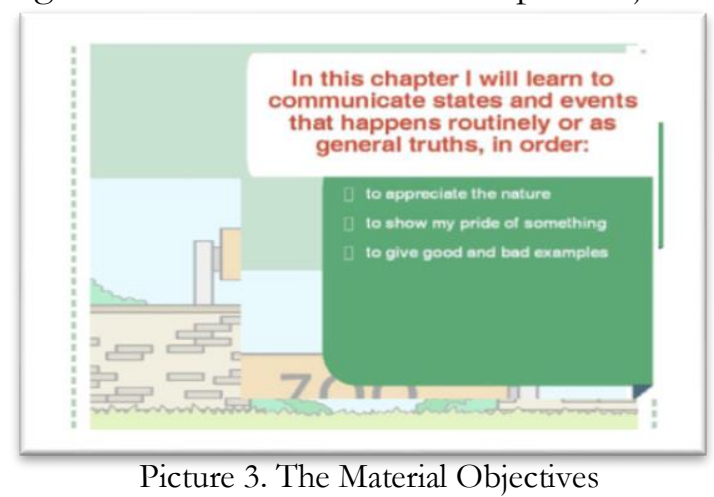

There was only one objective focused in the class when the observation was conducted. The objective was expecting the students to be able to explain about states. Thus, the materials given are full of some fruitful words or expressions that can be used in communicating states. The following figure is the example:

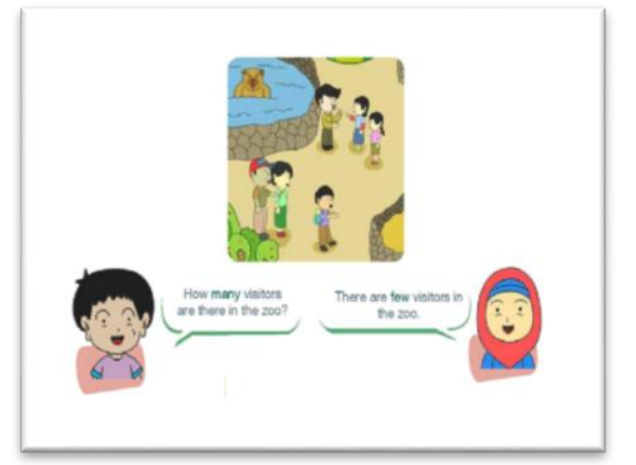

Picture 4. An Example of the Materials in the Textbook 
To support the materials, the teacher also arranges the procedures to teach. Using the scientific approach, the teacher orders the actions done from the observing up to the communicating.

Some quintessential words and expressions to communicate states had also been delivered by the teacher. From the field note, the teacher explained some words of quantity such as much, few, a lot of, etc. Besides, the students were also ordered to read some expressions related. The following excerpt of the field note might prove:

The teacher then asked some students in pairs to read a question with the answer in the textbook using a term few. From this, the students were asked about the meaning of few in Indonesian. The teacher then explained it. After that, the students were asked to read the expressions using term much. Again, the teacher asked the students about its meaning and the different use of much compared to many. The teacher explained the students about the countable and uncountable nouns.

Figure 14. Field Note of English Teaching

Furthermore, from the observation, it can be seen that the teacher optimizes the teaching of all English skills. From the beginning, the teacher spoke and gave written materials using English. Although sometimes she switched her language into Bahasa to give much understanding to the students, she emphasized more on English. These led the students to learn English through receptive skills. After listening and reading, the students were asked to read aloud some expressions. To make the learning process complete, the teacher finally instructed the students to do some written assignments, also using English.

\section{CONCLUSION}

As the curriculum changes, its impact is on the teaching and learning process, including English teaching in junior high schools. Related to 2013 Curriculum as the latest version, there is a revolution within its stages of teaching and learning process. It is so-called as Scientific Approach which covers observing, questioning, collecting information, associating, and communicating.

This approach is then harmonized with the approach in teaching English which is known as
Communicative Language Teaching (CLT). This approach comprises some axioms in which activate the students to be able to communicate well in the language learned. CLT emphasizes on the contextually and authenticity, so that the students can learn the materials as the whole part and can easily adjust their knowledge with the reality existing.

Through some analyses, the implementation of the latest curriculum does not neglect the framework of CLT. As the observation and document tracking were conducted, it is revealed that Scientific Approach and Communicative Language Teaching Approach can be harmonized within pursuing the teaching objectives. The teacher was seen to execute five phases each of which has inducted the principles of Communicative Language Teaching focusing on enabling the students to communicate well and contextually.

Despite the aforementioned facts, some suggestions are provided to the betterment of Indonesian education. The first is that the teacher needs to modify the ways of teaching, so that these are not too textbook-based. Furthermore, as CLT becomes the English teaching base applied, the need to consider the most prominent principle, which is bringing the process to be student-centered, emerge. The last, but not the least, is that the teacher is suggested to initiate and optimize the collaboration among the students, so that they can help one to another to structure the best understanding towards the materials.

\section{REFERENCES}

[1] Richards, J. C. \& Rodgers, T. S. (2003). Approaches and methods in language teaching. Cambridge: Cambridge University Press.

[2] Sreehari, P. (2012). Communicative language teaching: possibilities and problems. English Language Teaching, 5 (12), 87-93. October 19, 2012. https://files.eric.ed.gov/fulltext/EJ1080176.pdf

[3] Larsen-Freeman, D. (2000). Techniques and principles in language teaching. Oxford: Oxford University Press. 
[4] Asassfeh, S. M., et.al. (2012). Communicative language teaching in an EFL context: learners' attitudes and perceived implementation. Journal of Language Teaching and Research, 3 (3), 525-535. May, 2012. http://10.4304/jltr.3.3.525-535

[5] Thompson, G. (1996). Some misconceptions about communicative language teaching. ELT Journal, 50, 9-15. January 1, 1996. http://doi.org/10.1093/elt/50.1.9/

[6] Banciu, V. \& Jireghie, A. (2012). Communicative language teaching. The Public Administration and Social Policies Review, 8 (1), 94-98. June, 2012. http://www.revad.uvvg.ro/files/nr8/9.\%20Banc iu.pdf

[7] Chen, T. (2002). Reticence in class and on-line: two ESL students' experiences with communicative language teaching. System, 31, 259281. October 30, 2002. https://10.1016/S0346251X(03)00024-1

[8] Nishino, T. (2008). Japanese secondary school teachers' beliefs and practices regarding communicative language teaching: an explanatory survey. JALT Journal, 30 (1), 27-51. http://jaltpublications.org/recentpdf/ij/2008a/art2.pdf

[9] Jacobs, G. M. \& Farrell, T. S. C. (2003). Understanding and implementing the CLT (communicative language teaching) paradigm. RELC Journal, 34 (1), 5-30.

[10]Chang, M. \& Goswami, J. S. (2010). Factors affecting the implementation of communicative language teaching in Taiwanese college English classes. English Language Teaching, 4 (2), 3-12. November 26, 2010. http://file.eric.ed.gov/fulltext/EJ1080690.pdf

[11]Hiep, P. H. (2007). Communicative language teaching: unity within diversity. ELT Journal, 61, 193-201. July 3, 2007. http://doi:10.1093/elt/ccm026

[12] Ozsevik, Z. (2010). The use of communicative language teaching (CLT): Turkish EFL teachers' perceived difficulties in implementing CLT in Turkey. UrbanaChampaign: University of Illinois.

[13]Chang, M. (2011). EFL teachers' attitudes toward communicative language teaching in Taiwanese college. Asian EFL Journal Professional Teaching
Articles, 53, 17-34. July, 2011. https://www.asianefl-journal.com/monthly-journals/efl-teachersattitudes-toward-communicative-languageteaching-in-taiwanese-college/

[14]Republik Indonesia. Peraturan Pemerintab Republik Indonesia Nomor 19 Tabun 2005.

[15]Republik Indonesia. Peraturan Pemerintah Republik. Indonesia Nomor 32 Tabun 2013 tentang Perubaban Atas Peraturan Pemerintah Nomor 19 Tabun 2005 Tentang Standar Nasional Pendidikan.

[16]Savignon, S. J. (2006). Beyond Communicative Language Teaching: What's ahead?. Journal of Pragmatics, 39, 207-220. http://doi:10.1016/j.pragma.2006.09.004 